VOLUME 18 | ISSUE 6

December 2013

ISSN: 1092-8529

\title{
ᄀ
}
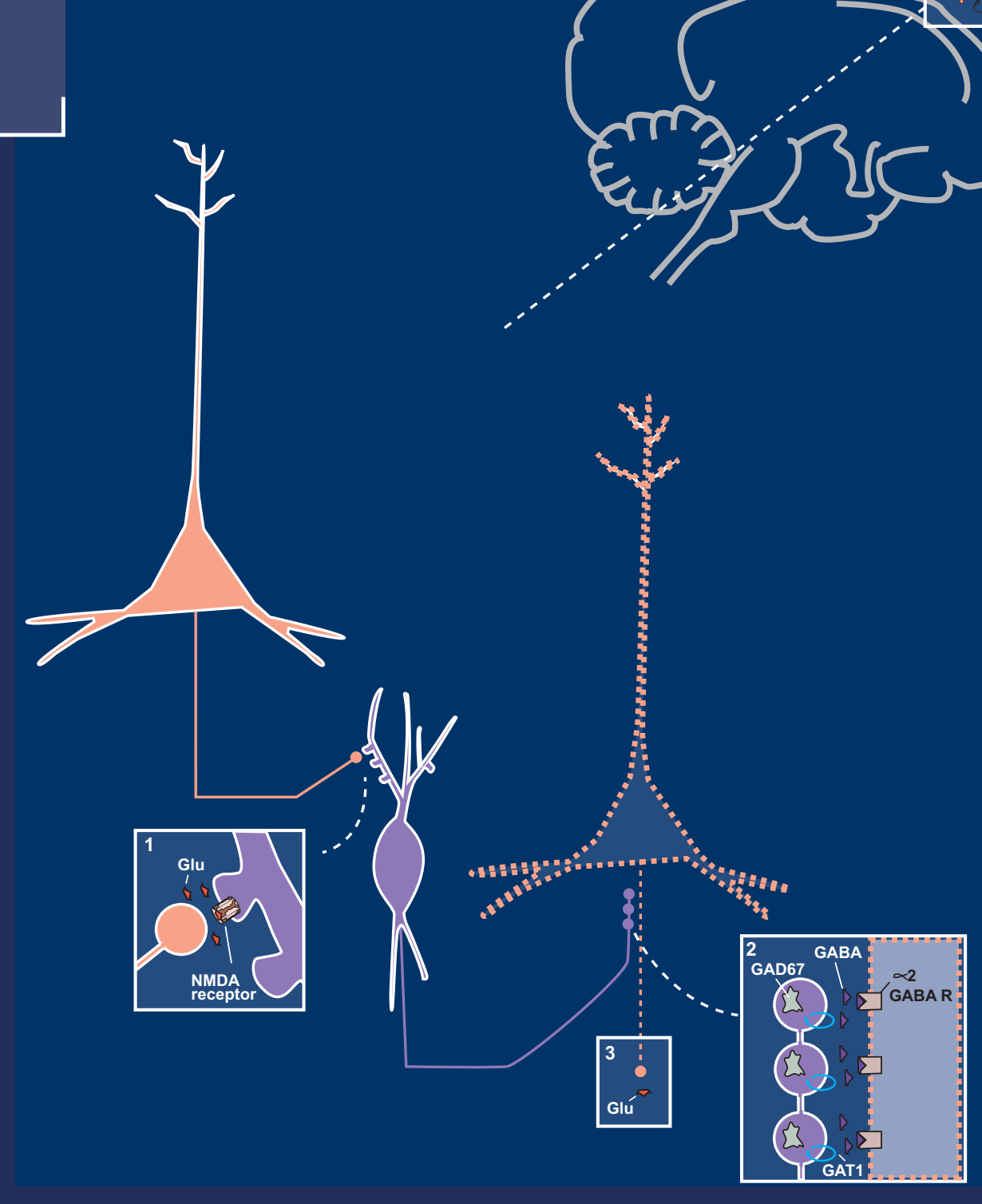

journals.cambridge.org/cns

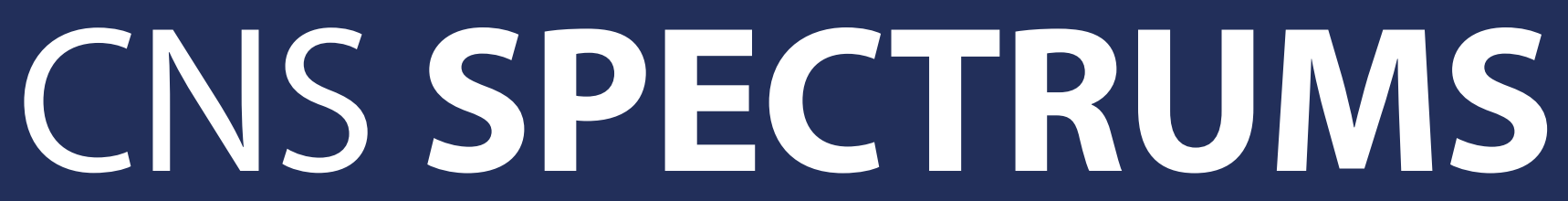

EDITOR-IN-CHIEF: STEPHEN M. STAHL 
Neuroscience

Education Institute

MAKE 2013 AN AMAZING

YEAR FOR YOUR

ADVANCEMENT IN

MENTAL HEALTH CARE.

2013 NE

\section{PSYCHO PHARMACOLOGY}

CONGRESS

COLORADO

SPRINGS

NOVEMBER

$14-17,2013$
Call us at

1-888-535-5600

or visit

www.neiglobal.com today!
Use promo code 2013EVENTS \& get $10 \%$ off registration rates.*

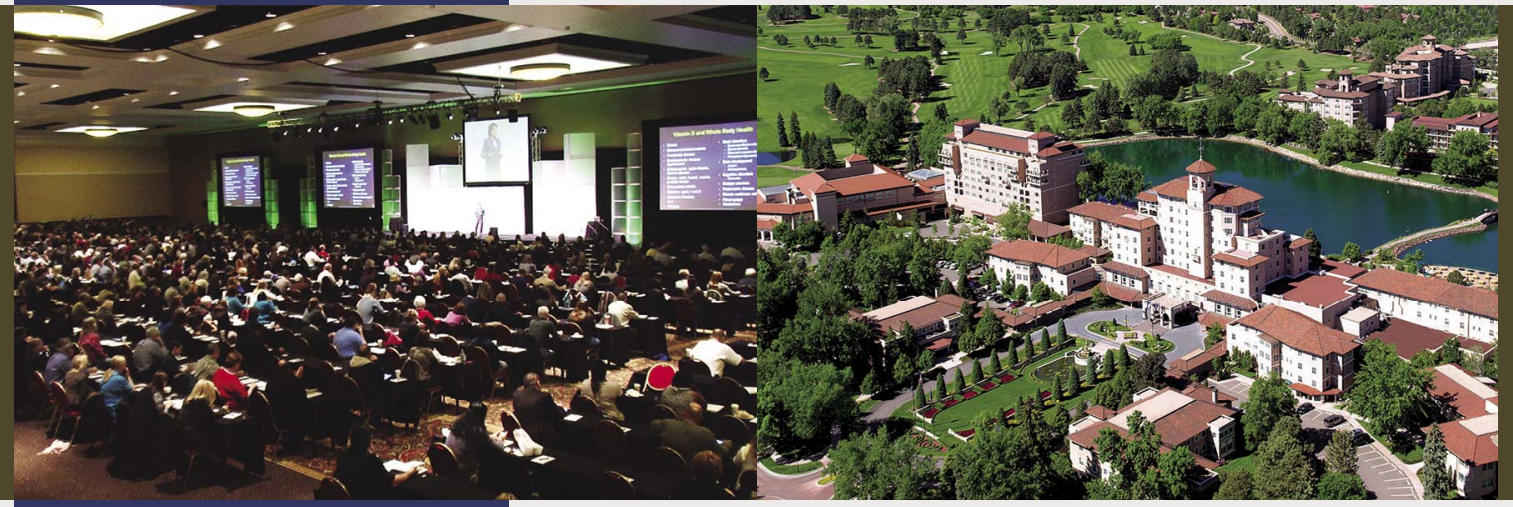

* Cannot be combined with other sales or promotions.
Attend the premier psychopharmacology event of the year.

- Inspiring content

- Elite speakers

- Latest in treatment strategies

- Comfortable seating 


\section{VOLUME 18 ISSUE 6 DECEMBER 2013}

\section{CNS SPECTRUMS}

\section{CONTENTS}

\section{BRAINSTORMS}

Role of $\alpha 1$ adrenergic antagonism in the mechanism of action of iloperidone: reducing extrapyramidal symptoms

Stephen M. Stahl

\section{REVIEW ARTICLES}

Pharmacotherapies for treating opioid use disorder

Thomas A. Nguyen, Jennie H. Hahn and Stephen M. Strakowski

Psychopharmacology and psychotherapy for the treatment of adults with ADHD-a systematic review of available meta-analyses

Tais S. Moriyama, Guilherme V. Polanczyk,

Fernanda S. Terzi, Kauy M. Faria and Luis A. Rohde

Incentive salience: novel treatment strategies for major depression

David P. Soskin, Daphne J. Holt, Garret R. Sacco and Maurizio Fava

ORIGINAL RESEARCH

Is there an association between cortical thickness, age of onset, and duration of illness in schizophrenia?

Idaiane Batista Assunção Leme, Ary Gadelha, João Ricardo Sato, Vanessa Kiyomi Ota, Jair de Jesus Mari, Maria Isabel Melaragno, Marilia de Arruda Cardoso Smith, Sintia lole Nogueira Belangero, Rodrigo Affonseca Bressan and Andrea Parolin Jackowski
Transcranial magnetic stimulation (TMS) for major depression: a multisite, naturalistic, observational study of quality of life outcome measures in clinical practice

Philip G. Janicak, David L. Dunner, Scott T. Aaronson, Linda L. Carpenter, Terrence A. Boyadjis,

David G. Brock, lan A. Cook, Karl Lanocha,

Hugh B. Solvason, Dafna Bonneh-Barkay

and Mark A. Demitrack

289 ABSTRACTS

The following abstracts were presented as posters at the 2013 NEI Psychopharmacology Congress 2013 NEl Global Psychopharmacology Congress 


\section{Editor-in-Chief}

Stephen M. Stahl, Adjunct Professor of Psychiatry at the University of California San Diego, USA; Honorary Visiting Senior Fellow at the University of Cambridge, UK.

\section{Field Editors}

Joseph F. Goldberg, Icahn School of Medicine at Mount Sinai, USA

Terence Arthur Ketter, Stanford University, USA

Gerard Sanacora, Yale University School of Medicine, USA

Thomas E. Schlaepfer, University Hospital Bonn, Germany

Carlos A. Zarate, National Institute of Mental Health, USA

\section{Deputy Editor}

Thomas L. Schwartz, SUNY Upstate Medical University at Syracuse, USA

\section{Editorial Board}

Dennis S. Charney, Mount Sinai School of Medicine, USA

Maria Conceição do Rosario, University of São Paulo Medical School, Brazil

Jeffrey L. Cummings, Cleveland Clinic, USA

Thilo Deckersbach, Harvard Medical School, USA

Koen Demyttenaere, University Psychiatric Center KuLeuven, Belgium

Karen D. Ersche, University of Cambridge, UK

Robert L. Findling, Case Western Reserve University, USA

Joseph F. Goldberg, Icahn School of Medicine at Mount Sinai, USA

Mark S. George, Medical University of South Carolina, USA

Eric Hollander, Albert Einstein College of Medicine and Montefiore Medical Center, USA

Daphne Holt, Harvard Medical School, USA

Peter B. Jones, University of Cambridge, UK

Andres M. Kanner, University of Miami, USA

Terence Arthur Ketter, Stanford University, USA

Anthony D. Loebel, New York University School of Medicine, USA

Donatella Marazziti, University of Pisa, Italy

Herbert Y. Meltzer, Northwestern University, USA

Mario F. Mendez, University of California, Los Angeles, USA

Philip Mitchell, University of New South Wales, Australia

Jun Nakamura, University of Occupational and Environmental Health, Japan

Humberto Nicolini, National Mexican Institute of Psychiatry, Mexico

Andrew A. Nierenberg, Harvard Medical School, USA

Stefano Pallanti, University of Florence, Italy

Katharine A. Phillips, Brown University, USA

Diego A. Pizzagalli, Harvard Medical School, USA

Mark H. Pollack, Rush University Medical Center, USA

Mark H. Rapaport, Emory University, USA

Irismar Reis de Oliveira, Universidade Federal da Bahia, Brazil

Trevor W. Robbins, University of Cambridge, UK

Peter P. Roy-Byrne, University of Washington School of Medicine, USA

Barbara J. Sahakian, University of Cambridge, UK

Gerard Sanacora, Yale University School of Medicine, USA

Alan F. Schatzberg, Stanford University School of Medicine, USA

Thomas L. Schwartz, SUNY Upstate Medical University in Syracuse, USA

Jordan W. Smoller, Harvard Medical School, USA

Dan J. Stein, University of Cape Town (UCT), South Africa

Stephen Strakowski, University of Cincinnati, USA

T. Scott Stroup, Columbia University, USA

Frank I. Tarazi, Harvard Medical School, USA

Michael E. Thase, University of Pennsylvania, USA

Michael Trimble, National Hospital for Neurology, Queen Square, London

Madhukar H. Trivedi, University of Texas Southwestern Medical Center, USA

Karen Dineen Wagner, The University of Texas Medical Branch, USA

Katherine D. Warburton, Department of State Hospitals, USA

Stephen R. Wisniewski, University of Pittsburgh, USA

Shigeto Yamawaki, Hiroshima University, Japan

Carlos A. Zarate, Jr., National Institute of Mental Health, USA

Joseph Zohar, Tel Aviv University, Israel

\section{Content Editor}

Lisa Arrington, Cambridge University Press (larrington@cambridge.org)

Cover Image: The image on the cover shows a hypothetical model whereby glutamate is released from an intracortical pyramidal neuron and binds to an NMDA receptor on a GABA-ergic interneuron. GABA is then released and binds to receptors on the axon of another glutamate pyramidal neuron. This inhibits the neuron, thus reducing the release of cortical glutamate. The GABA interneuron and its NMDA synapse from the first neuron to the second is the hypothetical site of glutamate dysfunction in schizophrenia.

Stahl's Essential Psychopharmacology, 4th edition, by Stephen M. Stahl

Copyright (C) 2013 Stephen M. Stahl. Reproduced with permission. 


\section{Aims and Scope}

CNS Spectrums aims to be the premiere journal covering all aspects of clinical neurosciences, neurotherapeutics and neurospsychopharmacology. From 2012 the journal will primarily focus on the publication of authoritative, cross-disciplinary review and opinion material publishing advances and controversial issues with pertinence to the clinician. In particular we aim to publish reviews and articles in translational neuroscience, biological psychiatry and neuropsychopharmacology that explain clinically relevant neuroscience discoveries in a way that makes these findings accessible and understandable to clinicians and clinical investigators. We will emphasize new therapeutics of all types in clinical neurosciences, mental health, psychiatry, and neurology, especially first in man studies and proof of concept studies. Our focus will be not just drugs, but novel psychotherapies and neurostimulation therapeutics as well. CNS Spectrums will in addition, continue to publish original research and commentaries that focus on emergent areas of research. Subject coverage shall span the full spectrum of neuropsychiatry focusing on translational issues and those crossing traditional boundaries between neurology and psychiatry.

\section{Submitting Manuscripts to CNS Spectrums}

All submissions to CNS Spectrums should be prepared in accordance with the instructions for authors and in the style of the Journal. Manuscripts should be submitted through the dedicated CNS Spectrums ScholarOne Manuscripts website: http://mc.manuscriptcentral.com/cnsspectr

CNS Spectrums will consider and encourage the following types of articles for publication: Review Article-Comprehensive article summarizing and synthesizing the literature on various topics presented in a scholarly and clinically relevant fashion; Original Research-Reports the results of a clinical study and contains original research; Opinion-Address a current topic of high interest, which has substantial evidence but has not yet been established; Commentary-An article that is written in reaction to previously published articles; usually encouraging a level of debate; the journal will also include Brainstorms and Editorials that shall be commissioned or written by the Editor in Chief.

\section{Instructions for Contributors}

The Instructions for Contributors are available on the Cambridge Journals Online web site at: http://journals.cambridge.org/CNSifc

\section{Indexing}

CNS Spectrums is indexed by Index Medicus/MEDLINE and Web of Science (Thomson Reuters) as well as appearing in the annual Journal Citation Report. Introduced in 1996, the journal was acquired in whole by Cambridge University Press in November of 2011.

\section{Subscriptions}

Institutional print and electronic: $£ 474 / \$ 750$; Institutional electronic only: £362/\$578.

\section{(C) Cambridge University Press 2013. All rights reserved.}

No part of this publication may be reproduced, in any form or by any means, electronic, photocopying, or otherwise, without permission in writing from Cambridge University Press. Policies, request forms, and contacts are available at: http://www. cambridge.org/rights/permissions/permission.htm. Permission to copy (for users in the U.S.A.) is available from Copyright Clearance Center http://www.copyright.com, email: info@copyright.com.

Rights \& permissions requests can be applied for online within each article by clicking "Request Permissions" within the table of contents or in the fulltext version of a specific article. Requests will be processed via the CCC Rightslink system and processed immediately.

CNS Spectrums (ISSN: Print 1092-8529; eISSN: 2165-6509) is published bimonthly by Cambridge University Press.

\section{Postmaster}

Send address changes in the U.S.A., Canada, and Mexico to CNS Spectrums, Cambridge University Press, Journals Dept., 100 Brook Hill Drive, West Nyack, NY 10994-2133, U.S.A. Send address changes elsewhere to CNS Spectrums, Cambridge University Press, The Edinburgh Building, Shaftesbury Road, Cambridge CB2 8RU, England.

\section{Online availability}

CNS Spectrums is hosted on the Cambridge Journals Online (CJO) service at http://journals.cambridge.org/cns

Institutional subscribers: Access to full-text articles online is only granted to subscription options offering an online component. Subscriptions must be activated by the purchasing institution using the instructions provided at the time of purchase; see information for subscribers at: http://journals.cambridge.org/

\section{Reprint and Advertising Sales}

Inquiries for bulk reprint sales and placement of advertising should be sent to the Journals Sales Department of Cambridge University Press: USAdSales@cambridge.org 


\section{CAMbridge}

\section{JOURNALS}

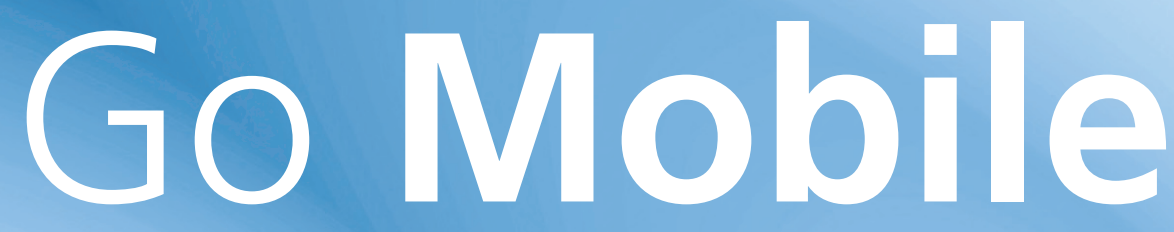

CJO Mobile (CJOm) is a streamlined Cambridge Journals Online (CJO) for smartphones and other small mobile devices

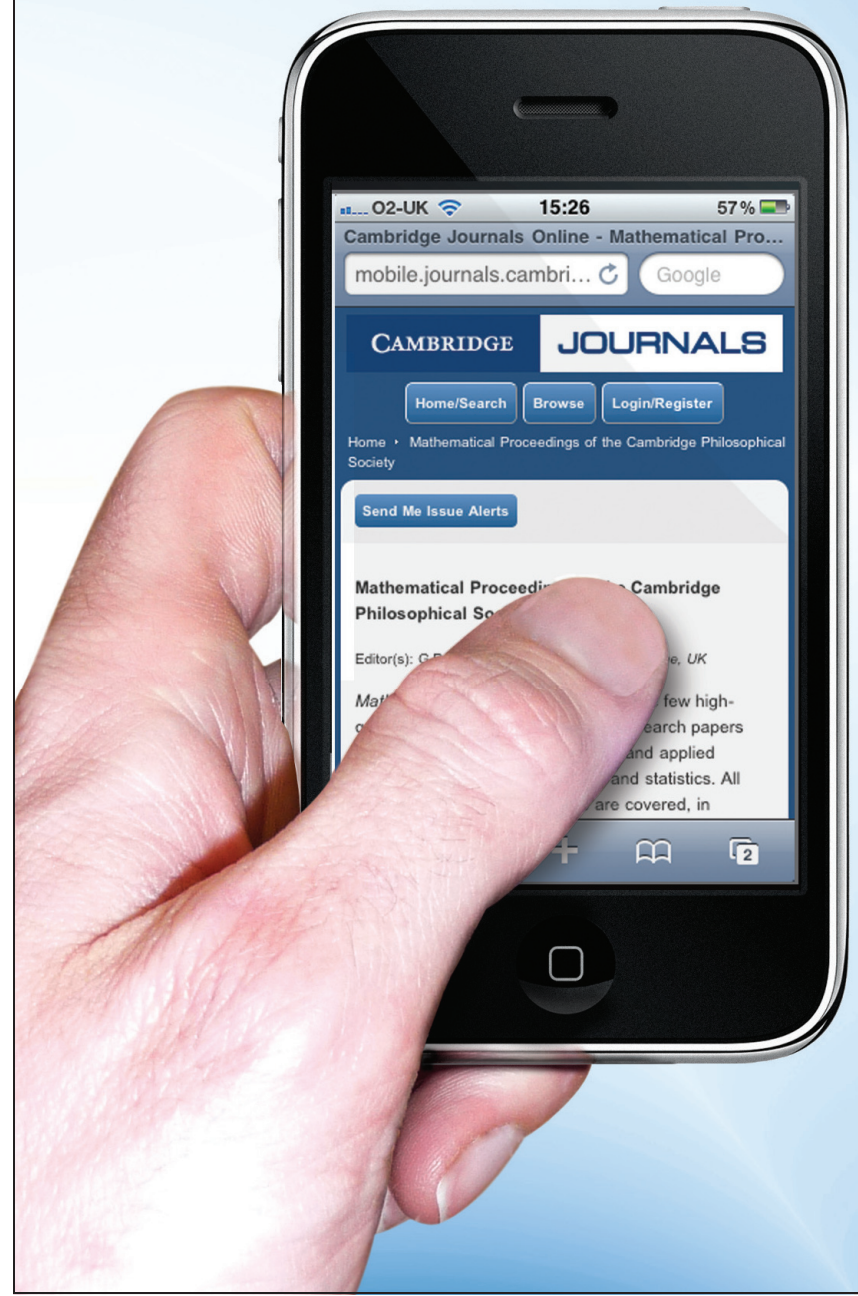

- Use CJOm to access all journal content including FirstView articles which are published online ahead of print

- Access quickly and easily thanks to simplified design and low resolution images

- Register for content alerts or save searches and articles they will be available on both CJO and CJOm

- Your device will be detected and automatically directed to CJOm via: journals.cambridge.org 